\title{
Early Lapita colonisation of Remote Oceania: An update on the leapfrog hypothesis
}

\author{
Peter Sheppard
}

\begin{abstract}
It is now more than 10 years since the original Lapita leapfrog hypothesis was proposed by Sheppard and Walter (2006) for the movement of Lapita out of Near Oceania into the south-east Solomon Islands. Data have continued to accumulate over the last decade and can be used to evaluate the original argument. This chapter will review new linguistic, genetic and archaeological data from the Solomon Islands and how they relate to the early colonisation of Remote Oceania.
\end{abstract}

\section{Introduction}

In 1979 Roger Green provided the first broad overview of Lapita archaeology (Green 1979) since the early summary by Golson (1971). At that time and given his evidence from the Southeast Solomons Culture History project, Green was confident that Remote Oceania was settled by Austronesian-speaking people carrying Lapita culture and that it was reasonable to hypothesise that these people had moved down from the Bismarck Archipelago, through the main Solomon Islands and out into the Reefs-Santa Cruz Islands of Temotu Province. There they were surmised to have established the first outpost in Remote Oceania (Green 1979:46), from whence they could have settled the rest of the Western Pacific. In Figure 2.12 of his 1979 paper, Green hypothesised that Lapita settlement would be found in some of the large lagoon systems of the main Solomons such as those of New Georgia and the Marau Sound area of eastern Guadalcanal. The only wrinkle in that overall scenario, at the time, was the supposed Papuan influence in the languages of Santa Cruz (Nendö) (Green 1976). This suggested that there was either an earlier Papuan settlement of areas of Island Melanesia in Remote Oceania or a later secondary Papuan movement, perhaps associated with the Mangaasi ceramics recovered by Garanger (1971) from Vanuatu. In his 1983 and 1988 papers, Green (Green 1988; Green and Mitchell 1983) considered the evidence for Pre-Lapita settlement of New Caledonia and concluded that the possibly early mounds there were 'For the Birds' or megapode constructions and that there was really no room for a Pre-Lapita Papuan settlement of eastern Island Melanesia. This left Remote Oceania to be initially settled by Austronesian speakers, with room perhaps for a later second wave of Papuan influence (Spriggs 1997:158-161). In the 25 years since Green's review, considerable progress has been made in our understanding of the development of Lapita and the early settlement of Remote Oceania 
as a result of new data from archaeology, linguistics and genetics. In this chapter I will focus on the role of the main Solomon Islands in that process; however, that role has implications for the broader process of settlement of Remote Oceania and the hypotheses surrounding that problem.

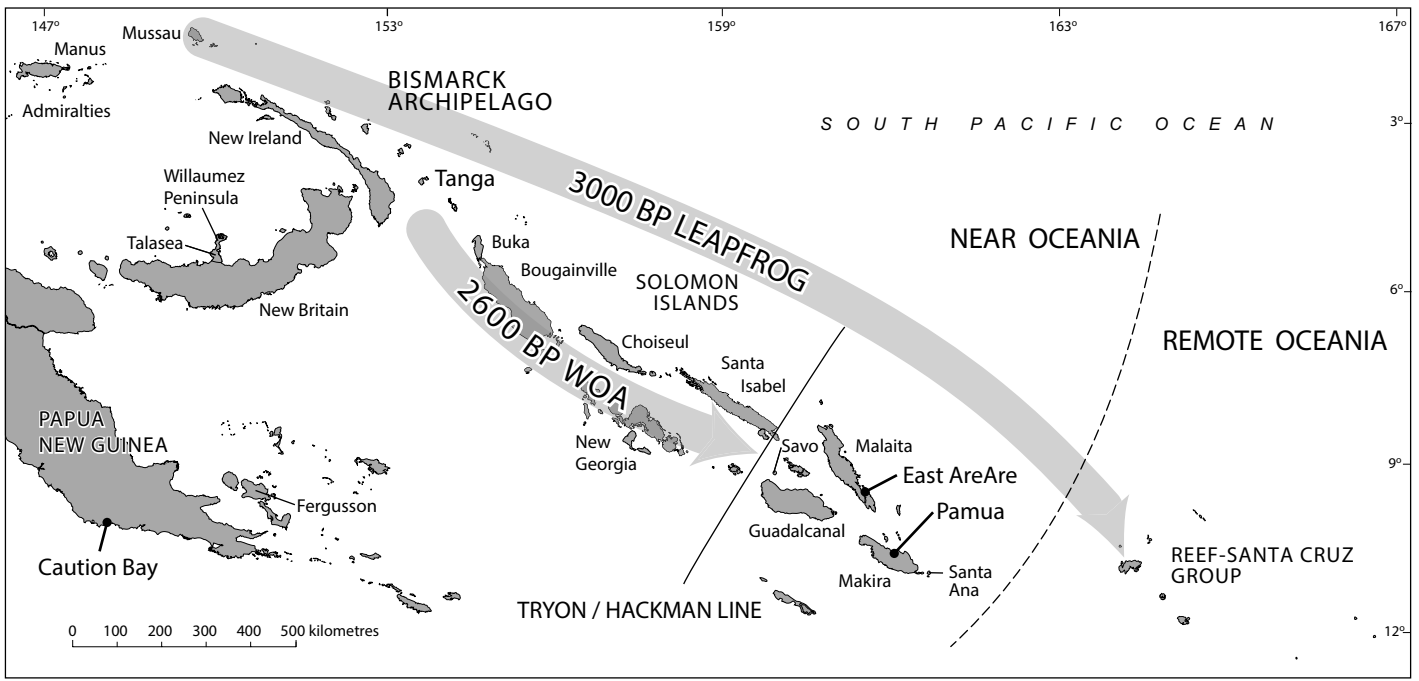

Figure 7.1. General map showing locations and movements discussed.

Source: Briar Sefton.

\section{The 2006 leapfrog hypothesis}

In 1979 Roger Green had some solid evidence indicating a role for the main Solomon Islands (Figure 7.1) in the Lapita settlement of Remote Oceania and specifically the Reefs-Santa Cruz group. That came in the form of chert, which looked very similar to chert recovered by the Southeast Solomons Culture History project from Ulawa in the main Solomons (Sheppard 1993; Ward 1976). In addition, a number of other exotic lithic materials were present, which could possibly have origins in the main Solomons or points further north (Green 1978). Whatever the origin of these materials, they certainly were unlike anything recovered archaeologically at that time in Remote Oceania. However, as noted by Green (1979:47), there was no evidence of Lapita occupation and barely any ceramics in the Eastern Solomons, with none having been found by the South-east Solomons project work on Ulawa or Makira and none recovered from the extensive excavations at Poha Cave (Vataluma Posovi) (Black and Green 1975) located just west of Honiara on Guadalcanal. There was a very small amount of poor-quality plainware recovered by Davenport (1972) and then Green from a number of cave and rock shelter sites on Santa Ana (Swadling 1976); however, Green described it as a separate cultural complex. In subsequent years, fieldwork in the Solomons, although limited in many areas, failed to find any dentate-ceramic bearing sites that could be clearly described as Lapita (Walter and Sheppard 2009). David Roe's work in west Guadalcanal and back at the site of Vataluma Posovi (Poha Cave) located deposits of Lapita age (Roe 1993), but no ceramics were recovered from any of his excavations or from anywhere else in the eastern Solomons, and there was also no historic record of pottery use or manufacture.

In the Northern and Western Solomons, pottery-bearing sites had been long recognised (Blackwood 1935; Chikamori 1967; Shutler and Shutler 1964) with ceramic production continuing into the late twentieth century on Bougainville and Choiseul. Jim Specht, in his PhD (Specht 1969), documented a long sequence in Buka and Bougainville and argued that the earliest Buka-style material, which he dated to c. $2450 \mathrm{BP}$, although undecorated must be derived from Lapita. John 
Terrell's (1976:214) surveys in southern Bougainville and along the north-east coast documented another ceramic sequence but also failed to find any pottery that he cared to relate to the Lapita tradition. Similarly, Geoff Irwin's (1972) survey in the Shortland Islands reported a considerable sequence but again failed to find anything with any obvious Lapita affiliation. Following on from the early work of Specht, Steven Wickler revisited many of the sites reported by Specht on Buka and Sohano Island in the Buka passage. His survey included three intertidal sites that contained diagnostic Lapita ceramics with significant proportions of dentate-stamp decoration (Wickler 2001). Wickler was unable to date these sites directly, but based on the proportion of dentatestamped sherds and a comparison to a dated sequence on Nissan (Spriggs 1991), he estimated the DJQ site, which had 56 per cent of the decorated sherds $(n=334)$ as dentate-stamped, to lie in the 3000-2800 BP range. The other sites had much less dentate-stamped material, with DAF having only 1.9 per cent dentate-stamped, with the remainder of the decorated sherds $(\mathrm{n}=4014)$ made up of incised, punctate and appliqué decoration (Wickler 2001:108) and a suggested age of 2800-2500 BP. Notched and crenulated rims similar to the 'pie-crust' rim decoration reported by Specht are common at these sites. It should be noted, however, that much of this ceramic was attributed by Wickler to the Sohano style, which he dates Post-Lapita (Wickler 2001:243).

In the mid-1970s, the Solomon Islands National Museum began an ambitious program of archaeological survey throughout the country led by Daniel Miller. In a number of unpublished survey reports, 700 sites were documented (Miller 1979). The reports for work in the Western and Choiseul Provinces of the western end of the country described numerous sites containing thin predominately plainware, which was generally felt to be late and related to the ceramic production on Choiseul, where pottery-making was still practised. There were, however, a number of locations where thicker decorated pottery was recovered. This was most notably at Nuatambu (SC-7-6) on the north-east coast of Choiseul, where Miller excavated through ceramic-bearing deposits that continued below the water table. The site produced incised pottery with crenulated rims. In 1989 Roland Reeves reported on a similar large intertidal site at Panaivili in Roviana Lagoon, which contained incised and appliqué-decorated ceramic with notched and crenulated rims, along with a small amount of obsidian (Reeve 1989). Reeve made explicit linkage of this material with Lapita from the Bismarck Archipelago. Stating that:

It may be that the Panaivili ceramics in some way represent a link between the late Lapita material encountered at sites like Watom, where incision and appliqué make up a higher percentage of the assemblage than in earlier Lapita sites (Green and Anson 1987:23), and the Mangaasi/Sohano ceramic traditions. (Reeve 1989:55).

Reeve noted that local people reported finding similar material at many points along the lagoon and that it was also found at Seghe at the Marovo Lagoon end of New Georgia, on the coast of north New Georgia and at Irigila on the north end of Vella Lavella.

In 1996, I initiated the New Georgia Archaeological Survey along with Matthew Felgate and Richard Walter. Felgate completed his PhD on intertidal ceramic assemblages from the western end of Roviana Lagoon (Felgate 2003). Walter and I conducted research throughout Roviana Lagoon and the mainland of New Georgia, subsequently working over a 10-year period on the islands of Rendova, Rannonga, Ghizo and Vella Lavella with a brief survey in Marovo Lagoon at the eastern end of New Georgia. Much of our work involved study of the later prehistoric and historic period; however, through excavation and survey we worked to understand the period represented by the Roviana intertidal sites and its probable Lapita ancestry (Sheppard et al. 1999).

By 2006 we had recorded more than 20 intertidal sites in the Solomons, demonstrating a dense record of settlement throughout all the islands of the New Georgia Group, focused primarily on sheltered lagoon settings (Sheppard and Walter 2006). A small number of pieces of dentatestamped ceramics had been recovered from sites in the Roviana Lagoon, producing a secure link 
to the Lapita ceramic tradition, and radiocarbon dates on carbon from two sherds indicated the earliest end of this sequence was of Late Lapita age (Felgate 2001). A much-improved understanding of the decorative and technological variation of these assemblages, thanks to Felgate's work (2003), allowed us more confidently to relate this ceramic design tradition to that found in Buka and in the New Ireland region (Golson 1991; White and Murray-Wallace 1996). The latter material dates to the same time period and is well summarised by Stephanie Garling in her PhD research (Garling 2003; recently published as Cath-Garling 2017).

Reflecting upon the available data in 2006, Sheppard and Walter (2006:48) proposed the following hypothesis:

In this article we show that these simplistic assumptions about the prehistory of the Solomons are repeatedly challenged as our knowledge of the archaeological record expands. Consequently, we propose a revised model, drawing upon archaeological, linguistic, biological and palynological data, that may be summarised by the following points.

1. The Solomon Islands archaeological record still has some gaps but is substantial.

2. The Lapita occupation of the Reefs-Santa Cruz Islands in the Early Lapita period leapfrogged the main Solomons, giving it some unique characteristics of significance for colonisation of Remote Oceania.

3. The northern and western Solomons as far as New Georgia were settled by Austronesianspeaking, food producing, ceramic making populations moving from the west over a NAN [nonAustronesian] substrate in the Late Lapita period.

4. The central and southeast Solomons east of the Florida Group in Near Oceania were similarly colonised in the Late Lapita period by aceramic food producing populations moving west from the area of the southeast Solomons in Remote Oceania (e.g. greater Reefs-Santa Cruz Group) that had initially been settled by early Lapita colonisers.

5. The boundary of these converging movements is marked in the central Solomons by the sharp linguistic division known as the Tryon-Hackman line.

Revisiting this hypothesis 10 years later, I would argue that, with the exception of the westward movement suggested in point four, the hypothesis stands up very well, with steady growth of supporting data. In the following I will update the different datasets reported upon in the 2006 paper.

\section{Archaeology}

\section{Summary of early ceramic sites}

Since 2006, the number of archaeologists working in the Solomons has grown and the areas and islands investigated increased (Figure 7.2). Tim Thomas has carried out many seasons of fieldwork on eastern Rendova and then on Tetepare, which is a very large uninhabited island lying east of Rendova and south of New Georgia. His work has replicated with some minor variation the historic and prehistoric sequences established in Roviana (Thomas 2009). Although he did not find any ceramic sites on Rendova, he did locate a ceramic site on Tetepare that contained ceramics identical in form and design to that found in Roviana intertidal sites. To the south of Tetepare, a team from San Diego State University (Haas et al. 2018) conducted an initial survey in 2015 on Simbo, recovering some ceramics from open and rock shelter sites, which appear to be like that dating to c. $550 \mathrm{BP}$ in Roviana. Further north on Isabel, Melissa Carter and a team from the University of Sydney supported by David Roe also carried out a significant amount of fieldwork with multiple field seasons over the period from 2006 to 2011 (Carter et al. 2012). Their work was concentrated in the Kia district of western Isabel, where they found terrestrial 
sites containing plainware dating to the last several hundred years and similar to material found in Roviana and most probably traded in from Choiseul. Coastal survey in the intertidal zone along the north-west coast of Isabel also found ceramics at the site of Kusira on Barora Fa Island (Carter et al. 2012), which is like that from the Roviana intertidal sites and, again, Late Lapita or Lapita-derived but without dentate ceramics. A brief survey by Roe at the eastern end of the island in the Bhugotu district also found a few pieces of thick plainware, which I have examined. It is possible that material is also of a similar age to the intertidal ceramics.

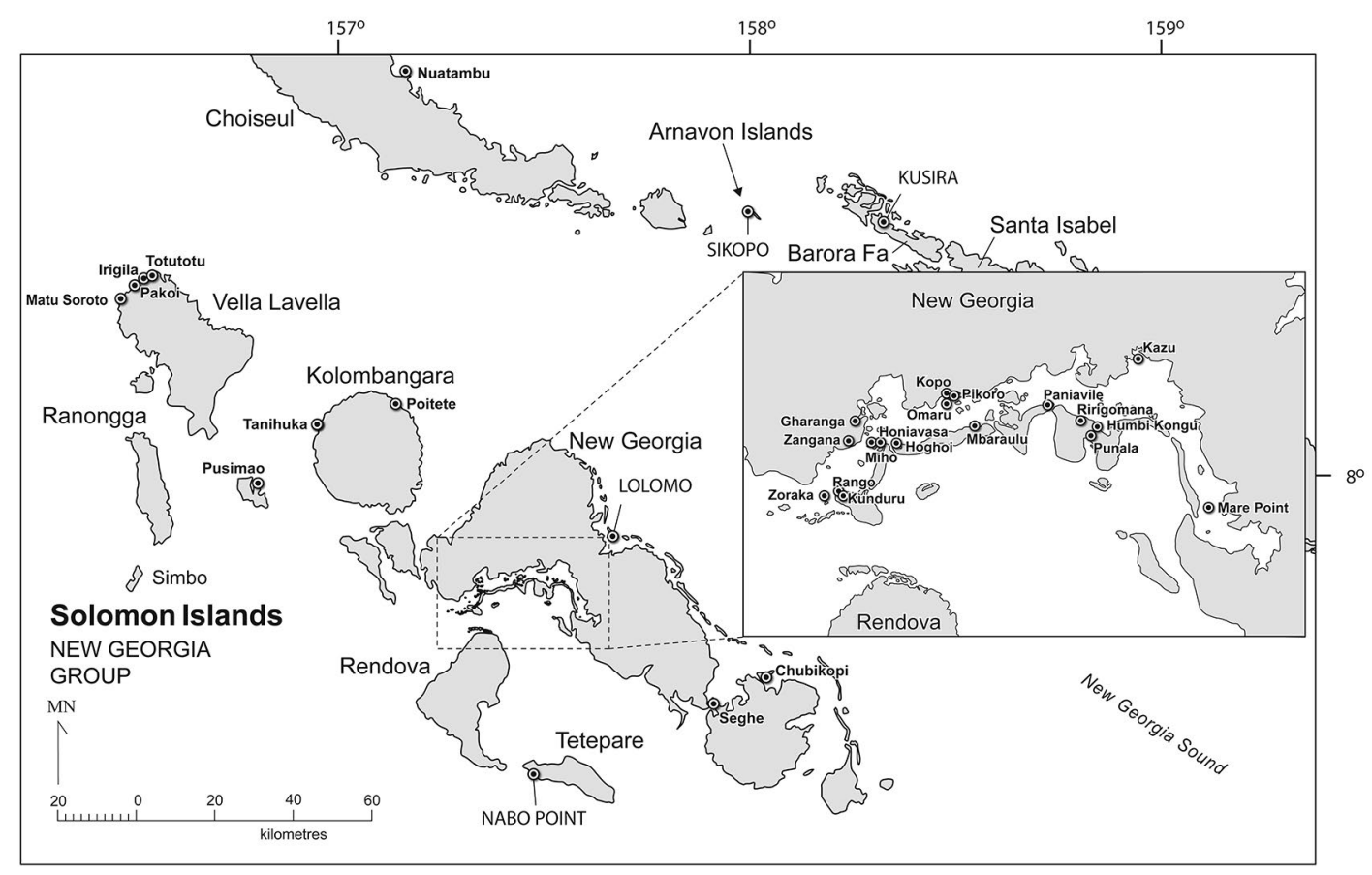

Figure 7.2. Western Solomons showing locations of intertidal ceramic sites.

Source: Briar Sefton.

To the west of Isabel, Walter has conducted some survey (2010-11) as part of a Nature Conservancy-funded project along the south-east coast of Choiseul and on the Arnavon Islands, which lie in the strait between Choiseul and Santa Isabel. This work located a ceramic site approximately $100 \mathrm{~m}$ inland on Sikipo Island in the Arnavon group (Richard Walter pers. comm. 2011). Further to the west, Rhys Richards has visited the intertidal site of Nuatambu on the north-east coast of Choiseul, which was first excavated and reported by Miller as part of the Solomon Island National Museum Survey (1979). Richards has published the results of his brief collection (Richards 2011), which included more of the incised ware reported by Miller and similar to that found at intertidal sites in the Solomons.

In summary, since 2006, the ceramic sequence reported from Roviana, and beginning with a very Late Lapita ceramic signature, has been replicated at an increasing number of sites beyond New Georgia resulting from the work of a number of teams over many seasons of fieldwork. One very intriguing discovery has been the sourcing of the distinctive quartz calcite hybrid ceramic temper reported initially by William Dickinson in samples from Felgate's (2003) work in Roviana and now known to be found in many more sites (Sheppard et al. 2015a), as being from Woodlark Island (Muyua) in the Massim region on the east coast of PNG (Tochilin et al. 2012). This is directly west across the Solomon Sea from the Western Solomons. It is tempting to link this Late Lapita movement out of the Bismarcks with a similar but possibly somewhat earlier movement from the Bismarcks south along the coast of New Guinea into the Port Moresby 
region (David et al. 2011). Although the general timing and impetus for this expansion may have been related, the ceramic traditions are not similar other than both having a Lapita origin (Sheppard et al. 2015a).

\section{Recent work in the Eastern Solomons}

In 2006, the amount of archaeological survey and excavation in the Eastern Solomons (i.e. the main Solomons east of New Georgia and Santa Isabel) was limited to the work of the Southeast Solomons Culture History project in Makira, Santa Ana and Ulawa (Green and Cresswell 1976), various surveys of the National Museum (Miller 1979), limited excavation in a rock shelter in the Florida Group (Ngella Pile) by the National Museum (Rukia 1989), the work of the ethnographer William Davenport on Santa Ana (Davenport 1972) and the excavations at Poha Cave (Vataluma Posovi) west of Honiara. Davenport had initiated the work at Vataluma Posovi but most of the excavation had been conducted by administrators in the colonial government (Russell 2003). As part of his PhD, David Roe tried to reconstruct, date and report the sequence at Vataluma Posovi and conduct new excavations in remnant deposits at the mouth of the cave. Additional survey and excavation were conducted at a number of other sites in the region, as well as survey at the western end of Guadalcanal (Roe 1993). Despite reporting a sequence that dated back through the Lapita time period into the mid-Holocene, Roe did not find any ceramics from any time period during his work on Guadalcanal.

Unlike the Northern and Western Solomons, there is no historic pottery tradition among the cultures of the Eastern Solomons and to date the only ceramics ever recovered in the area are a handful (c. 20 sherds) of small, thin, very friable shell-tempered plain sherds recovered from Feru and Rate rock shelters on Santa Ana, first by Davenport and subsequently by Green (Black and Green 1975). In 2009, I returned to Santa Ana and conducted test excavations at Manawoqwa Rockshelter just to the east of Nataghera village and also attempted to locate the Green excavations at Feru II. No ceramics were recovered in the Manawoqwa excavations, although the cultural deposit was thin and dating no earlier than 209 \pm 30 BP (Wk-26423, 68 per cent probability $272-150$ cal. BP) on charcoal. We were unable to relocate the deposits at Feru excavated by Green, although we tested just to the north of the still-open, very large excavation of Davenport. I subsequently submitted for dating some of the small charcoal samples collected by Green at Feru II and apparently associated with the stratigraphic unit containing the ceramic samples. The dates obtained by Green in the 1970s had very large errors of 250 years; however, the new charcoal AMS (accelerator mass spectrometry) dates of $2595 \pm 20$ BP (NZA-34638) and $2653 \pm 20$ BP (NZA-34639) provide a 68.2 per cent probability calibrated range for the older date of $2752-2726 \mathrm{cal}$. BP.

To the west of Santa Ana at Pamua on the north coast of Makira a team from the University of Sydney, led by Martin Gibbs and focusing on revisiting the Spanish colonial site associated with the Mendana expedition of 1595 AD (Gibbs 2011), has over a number of field seasons excavated at the village site of Mwanihuki. Excavation of a number of middens has shown the earliest to begin well within the Lapita time period (marine shell [Wk-37331] 3351 442 BP, 68.2 per cent probability 3022-3262 cal. BP; [Wk-37341] 3127 20 BP, 68.2 per cent probability 27612938 cal. BP). ${ }^{1}$ No ceramics were found in these early units or with the reoccupation some 1500 years later (Blake et al. 2015).

The island of Malaita has had very limited archaeological investigation. Prior to 2006 the only reported fieldwork was testing and survey by Miller (1980) in the Kwaio district of east Malaita. In 2012 Johannes Moser from the German Archaeological Institute in cooperation with the National Museum began ongoing fieldwork over a number of years in the East 'Are'Are region of

1 Calibration data from CALIB 7.0.2, marine04, $\Delta \mathrm{R} 44.73$ (Fiona Petchey pers. comm.). 
Malaita with excavation focused on the site of Apunirereha. This site is reported to be primarily a chert adze manufacturing area with the main period of use dating from 700 to $250 \mathrm{BP}$, although earlier occupation may be present (Johannes Moser pers. comm. 2013). What appears to be primarily a quarry area might not be very representative of material culture; however, to date Moser has not reported any ceramics from excavation or survey in that region.

\section{Genetic evidence}

In 2006 the biological evidence for the origins and relationships among Solomon Island populations was essentially limited to the work of Jonathan Friedlaender and colleagues on Bougainville and Santa Cruz (Friedlaender et al. 2002; Friedlaender et al. 2005a). Considerable genetic work was available (Friedlaender et al. 2005b; Merriwether et al. 2005) and underway in the Bismarck Archipelago, but the main Solomons (Cox and Lahr 2006), and most of Island Melanesia in Remote Oceania, was very poorly known. In 2006 we argued that the genetic evidence indicated a closer relationship between samples from Santa Cruz and the Bismarcks than between Santa Cruz and the main Solomons:

In short, mitochondrial DNA research suggests strong linkages of the Reef/Santa Cruz samples with samples from New Britain and neighbours to the south in Remote Oceania. Samples from Bougainville and the undifferentiated Solomons sample are generally similar with some indication of connection to New Ireland. From this we can conclude that there is no evidence of a Solomons Lapita mitochondrial signal into Remote Oceania, although more detailed work in the Solomons is required to see if there is a Reefs-Santa Cruz genetic signal back into the eastern Solomons (Sheppard and Walter 2006:62).

Since 2006 there has been a great deal of publication on the genetics of the Bismarck Archipelago and much better sampling and study of the main Solomons and the Reefs-Santa Cruz. There is still limited study of Vanuatu (Cox 2007) and New Caledonia (Kouneski 2009) and most consideration of genetic history in the region is dependent on small older samples with apparently limited genealogical data (Friedlaender et al. 2007; Kayser 2010). Most recently, and after this paper was initially submitted, much more work has been published for Vanuatu, and most significantly on ancient DNA from the Pacific (Skoglund et al. 2016; Lipson et al. 2018; Posth et al. 2018).

Delfin et al. (2012) have reported on the first comprehensive genetic study of the Solomon Islands, which has sampled mitochondrial DNA (mtDNA) and nonrecombining Y chromosomes (NRY) from over 700 individuals in 18 populations in the Solomons, from Choiseul in the west to Tikopia in the east, including 46 individuals from villages on the south-western and north-eastern coasts of Santa Cruz. Earlier work on Santa Cruz reported by Friedlaender and colleagues (2002) had sampled from the western coast of Graciosa Bay, which is the location of the provincial capital Lata, an area with high degrees of external interaction and settlement.

This detailed study reached a number of interesting conclusions (Delfin et al. 2012:561):

1. NRY data suggested a relatively old colonisation of the main Solomons, at least by 9200 years ago.

2. No significant genetic difference between speakers of Austronesian and Papuan languages, as would be expected given the high degree of intermarriage in areas such as Vella Lavella (Sheppard et al. 2010).

3. The Polynesian Outliers, and especially Rennell and Bellona, show evidence of significant genetic isolation with the frequency of mtDNA haplogroups, which likely came from Polynesia at 100 per cent. 
4. There was poor fit of the genetic data to the Tryon-Hackman line, which divides in an east-west split the major Oceanic Austronesian language families (Meso-Melanesian vs Southeast Solomonic) in the main Solomons.

5. The major source of Solomon NRY and mtDNA is from the Bismarcks, although as indicated in Delfin et al.'s Figure 7, the closest connections are with New Ireland and New Hanover.

6. Santa Cruz is remarkably unique in their dataset with unusually low frequencies of NRY and mtDNA haplogroups of 'Asian' origin, which makes it very unlike its neighbours to the west or Polynesia.

7. The main Solomons 'appear to be the main source of Remote Oceanian NRY and mtDNA types' (Delfin et al 2012:561).

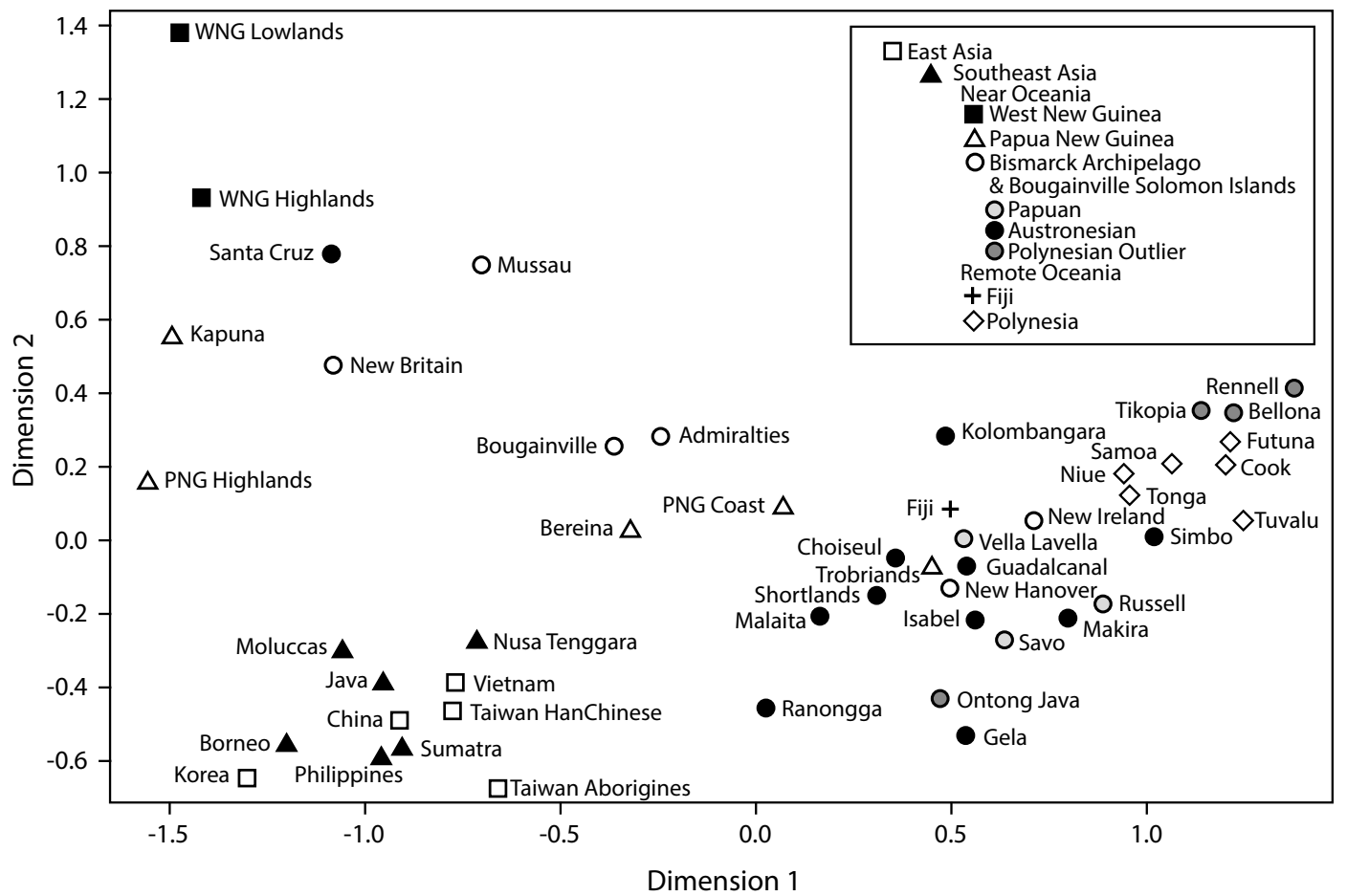

Figure 7.3. Multidimensional scaling plot based on $\Phi$ st distances calculated from mtDNA HV1 sequences from Solomons and reference groups.

The stress value is 0.089 .

Source: Adaptation of Delfin et al. (2012: Figure 7a), with permission of Oxford University Press.

The surprisingly unique nature of Santa Cruz genetic data, given its apparent primary role in the settlement of Remote Oceania by Lapita, had been noted by Friedlaender and colleagues (2002) and, although data suggested some connection with New Britain, those authors suggested the data indicated a complex, possibly Pre-Lapita, genetic history for what was then considered a non-Austronesian-speaking population. The results of Delfin et al. (2012) for Santa Cruz are even more striking, as they record an even lower amount ( 15 per cent) of putative Asian mtDNA on Santa Cruz, much less than the average of 80 per cent in the main Solomons samples, and an 'extraordinarily high' frequency ( 85 per cent) of Near Oceanian mtDNA. They suggest a number of scenarios to explain this: 
Santa Cruz is a conundrum, as archaeological and linguistic evidence indicate that it was colonized relatively soon after the arrival of Austronesian speakers in Near Oceania, and yet it has unusually low frequencies of NRY and mtDNA haplogroups of Asian origin. Possible explanations include: pre-Lapita settlement of Santa Cruz followed by language shift when Austronesian speakers arrived; a rapid language and cultural shift by a PAP [Papuan] group in the Bismarcks after the arrival of Austronesians there that subsequently colonized Santa Cruz; or gradual genetic replacement due to the ongoing extensive contact with the Bismarcks following initial colonization. Regardless of the explanation, Santa Cruz has clearly remained genetically isolated from the rest of the Solomons (Delfin et al. 2012:561).

Regardless of its role in the settlement of Remote Oceania, where might we find a genetic source or origin for Santa Cruz? The mtDNA variation summarised in Delfin et al. (2012: Figure 7a) (reproduced here as Figure 7.3), like the results of Friedlaender and colleagues (2002), suggests a Bismarcks source with Santa Cruz closest to Mussau, which is itself a comparative outlier, or (as had been also indicated by Friedlaender) closest to New Britain. However, as is often the case, the NRY data shown in their Figure 7b show a different pattern for male DNA, with Santa Cruz closest to Malaita, and Mussau and New Britain clustering with a tight grouping from the Western and Northern Solomons. It should be noted, however, that the most common NRY haplogroup in their main Solomons data $\left(\mathrm{M} 2-\mathrm{M} 353^{*}\right)$ is absent from Santa Cruz, indicating a low probability of any direct relationship with the main Solomons.

Subsequent research by Duggan et al. (2014) in a comprehensive survey of 1331 whole mitochondrial genome sequences from 34 populations, spanning Near and Remote Oceania and including the Solomon Islands dataset, has closely investigated the alternative hypotheses proposed by Delfin et al. (2012) for Santa Cruz. They have concluded:

Thus, it is unlikely that the high frequency of Near Oceanian haplogroups reflects a recent bottleneck or founder event in Santa Cruz. The people of Santa Cruz speak an Austronesian language, recognized now as probably a deep branch within the Oceanic family of Austronesian, yet they are starkly different genetically from all other Remote Oceanian populations and from Austronesian-speaking populations in Near Oceania (Duggan et al. 2014:727).

In addition, we do not find evidence to support a pre-Austronesian settlement of Santa Cruz, which remains a strong outlier in Remote Oceania because of its extraordinarily high frequency of autochthonous Near Oceanian haplogroups (Duggan et al. 2014:730).

Although it is clear from the genetic data that Santa Cruz is very distinct and unlike its Solomons neighbours or Polynesians, it also does not seem, given available limited data, to have a very closely shared history with its neighbours to the south. As noted by Friedlaender and colleagues (2007:4), like Santa Cruz, Vanuatu, New Caledonia and Fiji have considerable amounts of mtDNA of Near Oceanian origin including the M28 haplogroup, which has its centre of diversity in East New Britain but was rare in his data from New Ireland, Bougainville, the central Solomons and Polynesia. On the other hand, the B4ala1 haplogroup, or 'Polynesian Motif', which is uncommon in the New Britain area, often common but variable in frequency in the main Solomons, and virtually absent from Santa Cruz, is found in the Friedlaender et al. (2007) dataset at low frequency in Vanuatu and Fiji and of course at very high frequencies in Polynesia. A similar scenario seems to hold for New Caledonia, where recent mtDNA analysis of older archived samples (Kouneski 2009) with limited genealogical control reports:

Forty-four percent of the New Caledonian population had Near Oceanic mtDNA haplogroups. No population in Polynesia has ratios of Near Oceanic haplogroups higher than seven percent, except for Fiji, which has a prevalence of twenty percent (Kayser et al. 2006). Studies have identified a structured loss of diversity in Polynesian mtDNA from the western to eastern islands (Kayser et al. 2006). In contrast, diversity levels on La Grande Terre remain high; New Caledonia does not conform to this clinal pattern (Kouneski 2009:154). 
In summary, the genetic data strongly support the leapfrog hypothesis from the Bismarcks to Santa Cruz with isolation from main Solomons influence. To the south of Santa Cruz, the genetics indicate a more complex scenario with a more diverse set of genetic influences, probably multiple sources in the Bismarcks, where putative 'Asian' haplogroups are found in variable amounts. Further research in Vanuatu is needed to investigate any relationship with the main Solomons, which remains a possibility, although the virtual absence in Remote Oceania of the most frequent NRY haplogroup in the main Solomons (M2-M353*) might suggest it has a limited role. Recent data also indicate limited contact across the Solomon Sea from the Solomons to the Massim region of PNG (van Oven et al. 2014).

I add here a brief comment on the most recent 2018 data, which the editors have allowed me to add to this paper. Skoglund et al. (2016) reported on success in extracting ancient DNA from three Lapita-age skeletons from the Teouma site in Vanuatu and one from Tonga. Analysis of this data indicated to the authors that these Early Lapita people were derived from an 'East Asian' DNA population with little or no evidence of admixture in Near Oceania. In the Principal Components Analysis they provide as Figure 1b, the Lapita samples in fact plot tightly off by themselves and not in with the 'Polynesian' samples nor in with the 'East Asian' samples, although closest to those from the Northern Philippines - so they are unlike any modern samples. The recent papers by Posth et al. (2018) and Lipson et al. (2018) build on this result in a very commendable fashion by extracting ancient DNA from a large sample (19 and 14, respectively) of prehistoric human remains from across the Pacific and through time, and in addition collecting additional DNA from modern Ni-Vanuatu (27 and 185 samples respectively). Both papers conclude that the earliest Lapita individuals are unlike any modern populations in Near Oceania, including the Solomon Islands, while all the Post-Lapita individuals_-including an individual dating to 2630-2350 cal. BP (TAN002) from Tanna in southern Vanuatu and the modern Ni-Vanuatu in Remote Oceania - are closest to modern samples from Santa Cruz or the Bismarck Archipelago and explicitly not the Solomon Islands, confirming the leapfrog hypothesis (also confirmed by Pugach et al. 2018). Unfortunately, the Posth et al. (2018) paper conflates genetics, language and culture, leaving us with such mysteries as the movement of 'Papuan' people, who are assumed to speak Papuan languages, replacing the 'Asian' Lapita people (who are assumed to have spoken Austronesian), yet retaining the Austronesian language. In my opinion, the hypothesis proposed by Pawley (2006) and discussed below may ultimately prove more accurate.

\section{Linguistic evidence}

In 2006 we reported no linguistic evidence to support the leapfrog hypothesis other than the fact that the languages of Santa Cruz were considered not to be simply non-Austronesian (Papuan), but a mixed non-Austronesian/Austronesian language. We quoted the following from Lynch et al. (2002), which did suggest that the Austronesian languages of the islands just to the south of Santa Cruz, in the Temotu Province, were very distinctive and not easily related to Southeast Solomonic of the Eastern Solomons:

The islands of Utupua and Vanikoro each have three Oceanic languages, and those of Utupua in particular bear marks of Oceanic-Papuan contact. Perhaps more significantly, however, the six languages show an unexpected measure of diversity for the size and proximity of the islands, and, although we can recognise an Utupua family and a Vanikoro family, there are seemingly no innovations which allow us to attribute all six languages to a single group, let alone to relate them to the Southeast Solomonic or to the Southern Oceanic linkage (Lynch et al 2002:112, citing Tryon 1994; Tryon and Hackman 1983:70-71). 
Lynch et al. (2002) concluded their observations on these languages of the Temotu region by suggesting they represented first order separation from their neighbours and, given the amount of diversity, considerable age and isolation, perhaps dating to the time of Early Lapita occupation of the Reefs-Santa Cruz Islands. Considerable linguistic research since 2006 (Naess and Boerger 2008; Ross and Naess 2007) has shown that the languages of Temotu Province of the Solomon Islands (Santa Cruz, Reefs (excluding the Polynesian languages), Vanikoro and Utupua) are Austronesian and not mixed languages and, as suggested by Lynch et al. (2002) and earlier by Lincoln (1976), are a first order subgroup of Oceanic.

This led Ross and Naess (2007) to conclude:

The apparent lack of early Lapita settlements in the Solomons has caused Sheppard and Walter (2006) to propose that Lapita settlers somehow leapfrogged the Solomons to arrive in the Temotu area. It is not our brief to engage in archaeological argument, but if the Temotu languages form a primary subgroup, then this suggests that the arrival of their ancestors was separate from the arrivals of either the Southeast or Northwest Solomonic groups in the areas they currently occupy [i.e. the main Solomon Islands] (Ross and Naess 2007:461).

As for the possible source or area from which these languages might be derived, or share a common history, they suggest:

the Temotu languages form a subgroup, and this subgroup is not part of any other known subgroup of Oceanic - with one possible exception. That is, Temotu is not especially related to the Admiralties, Western Oceanic, Southeast Solomonic, or Remote Oceanic grouping (the integrity of the last is in any case open to question). There is, however, evidence that connects it with the tiny St. Matthias group, consisting of just two languages, Mussau and Tench, located to the north of New Ireland and to the east of the Admiralties (Ross and Naess 2007:471).

Subsequent work has shown additional similarities with the St Mathias group (Naess and Boerger 2008), supporting a very early break from Proto-Oceanic, while the phylogenetic analysis of Gray et al. (2009) of a comprehensive set of 400 Austronesian languages also supports this interpretation.

Gray et al.'s (2009: Figure 1) phylogenetic tree also shows the languages of Vanuatu and New Caledonia as clearly a distinct grouping from those of Temotu and having some internal complexity. This raises the issue of proposed 'Papuan' influence creating some of what Pawley has described, following Grace, as the 'aberrant' nature of those Austronesian languages (Pawley 2006). Pawley's review of the history of debate over the nature of these languages has led him to suggest that Early Lapita colonisers may have included considerable linguistic and biological variation:

The Lapita colonisation of Remote Oceania was astonishing in its speed and scale. Dozens of new settlements were founded in different parts of Remote Oceania within a century or two, and this must have involved the movement of considerable numbers of people organised by ambitious and adventurous leaders. It is hard to imagine that the Oceanic-speaking Lapita migrants could have accomplished this rapid colonisation without recruiting men and women from non-Oceanic speaking communities that they came in contact within Northwest Melanesia. Whether they were recruited as spouses, as slaves or in some other role, we may never know. That is not to say every Lapita canoe setting sail for Remote Oceania carried some passengers of Papuan stock, only that some vessels did (Pawley 2006:247).

Subsequently Blust—who has argued, based on linguistics, for a two-wave model of Papuan and then Austronesian settlement in remote Island Melanesia (Blust 2005)—has arrived at what appears to be much the same conclusion, of a Lapita expansion that involved considerable linguistic and biological diversity (see also Donohue and Denham 2008): 
There has been a tendency to think of Papuan speakers as hunkering down and holding their own in this situation. But contact with Proto-Oceanic speakers could have dislodged some Papuanspeaking groups and influenced them culturally before much gene flow had occurred. With a basic knowledge of the newly learned outrigger canoe complex, pottery, and some other elements of material culture, these groups, still speaking Papuan languages, could have left their home territories in the wake of the Austronesians, or together with them. In this way, Remote Melanesia would have been settled simultaneously or in rapid succession by both SM [Southern Mongoloid] AN [Austronesian] speakers and Papuan speakers (Blust 2008:456).

In summary, it seems clear that the Lapita settlement of Remote Oceania is, from a linguistics perspective, the result of an early movement directly out of the Bismarck Archipelago, with sampling from a number of source areas contributing to some linguistic diversity in the founding populations. In the main Solomons we are still left with a question over the origins or external relations of Southeast Solomonic and its relationship to Meso-Melanesian, which are marked by significant linguistic difference noted as the Tryon-Hackman line, which divides the central Solomons (Ross 1988). In 2006 Sheppard and Walter proposed that the Meso-Melanesian group, which extends down from New Ireland through the Western Solomons, could be associated with the Late Lapita expansion into the Western Solomons, and that the aceramic cultures of the Southeast Solomonic region might be associated with a back movement out of Remote Oceania, at a time when ceramics had ceased to be made in the Temotu region. Pawley (2009:535) has argued that the movement and timing we suggested for Meso-Melanesian are consistent with the linguistic evidence. However, there is no obvious evidence for the source of pre-Southeast Solomonic, albeit some scraps of evidence that could suggest 'a brief shared history with certain other languages of Remote Oceania, especially those of Vanuatu, Fiji, Polynesia and Micronesia but the evidence is far from decisive' (Pawley 2009:536).

\section{Discussion and conclusion}

Consideration of the new archaeological, genetic and linguistic data from the Solomon Islands and Island Melanesia has confirmed the leapfrog hypothesis_-and in fact the alternative, such as a settlement of the Temotu region from the nearest neighbours to the west, is totally inconsistent with available data. This of course does not preclude contact with or knowledge of the main Solomons. The Solomons chain, stretching south-east from the Bismarcks, would have extended the sailing 'nursery' Irwin (1989) has suggested existed for Lapita navigators $1100 \mathrm{~km}$ beyond the Bismarcks. Sailors reaching the end of the Solomons chain at Ulawa would most certainly have stocked up on supplies of food and water and exotic materials such as chert, which is clearly from Malaita and/or Ulawa (Sheppard 1996), before setting off on their first major voyage beyond sight of land. Following seasonal winds and a simple zenith star path (Irwin 2008), they would have had a relatively short distance out of sight of land before sighting the high $(400 \mathrm{~m})$ island of Santa Cruz $400 \mathrm{~km}$ to the east of Ulawa. At that point they entered a new sailing 'nursery' of inter-visible islands extending south from the islands of Temotu to Vanuatu (Irwin 2008). It is this leapfrog that helps explain the rapidity of the initial Lapita expansion into Remote Oceania at c. 3000 cal. BP (Sheppard 2011; Sheppard et al. 2015b).

The movement out into Remote Oceania by people bearing the Lapita culture was extremely fast. It is conceivable that within a few generations all of the islands of southern Island Melanesia were settled and supported multiple population centres, perhaps as a result of multiple withinisland leapfrogs to resource-rich locations (Kennett et al. 2006). Such rapid early explorations and settlements are known from many Pacific archipelagos such as New Zealand (Walter et al. 2010). The size of founding populations or number of episodes of exploration and settlement are very hard to estimate, other than perhaps from genetics or oral history. Both the genetic and 
linguistic evidence indicate considerable input into the settlement process of Western Remote Oceania by people carrying some ancient biological and linguistic heritage from the Bismarck Archipelago, generally referred to as 'Papuan', versus an 'Asian' component generally associated with Austronesian language and some genetic haplogroups such as the 'Polynesian motif'. The origins and timing associated with the linguistic and genetic components of the 'Asian' complex is increasingly debated (Donohue and Denham 2010; Soares et al. 2011; Spriggs 2011), although it has routinely been viewed as expressed archaeologically by the Lapita culture. Genetic study of modern populations in the Bismarck Archipelago and the Solomon Islands has regularly shown no simple association between language, genetics and culture, and considerable genetic diversity among populations. This is not at all surprising, given the known history of intermarriage, migration and interaction (e.g. Sheppard et al. 2010) in many areas; a history that presumably has ancient roots going back into prehistory.

Given the very high level of genetic and linguistic diversity seen in the Bismarck Archipelago today, it seems very probable that soon after food production was established and populations increased, similar patterns began to arise. There seems to be no doubt that a Lapita cultural tradition, or community of practice, arose within the Bismarck Archipelago under the influence of the development of Neolithic economies to the north and east. This cultural tradition became established throughout most of the region, where it would have at least interacted closely with earlier traditions, if not integrating and replacing them and eliminating any simple association between biology, language and culture, much as we see today (Welsch et al. 1992). The rapid settlement of Remote Oceania by groups of Lapita settlers sampling the geographic variation in the Bismarcks would have replicated, at least initially, that variation in Remote Oceania. One example of such sampling is provided by Santa Cruz, where it seems a unique biological and linguistic heritage was maintained, given the comparative isolation of the region, for many thousands of years. Another example would appear to be directly given by recent analysis of the Lapita crania from the cemetery site at Teouma in Vanuatu (Valentin et al. 2016). Morphometric analysis of five Teouma crania, which are compared to modern samples of Tolai from East New Britain, representing Melanesia and a number of populations from East Polynesia (Hawai'i, Easter Island, Moriori and Mãori), indicate the Teouma samples are variable but statistically within this dataset, most like those from Polynesia (also confirmed now by DNA). Although Chowning (1982:50) has been critical of the use of the Tolai by Howells (1973) as representative of the variability present in 'Melanesia', the Teouma data demonstrate a much more Polynesianlike result than has been obtained from Lapita associated burials in the Bismarcks or Late or Post-Lapita human remains from southern Island Melanesia (Pietrusewsky et al. 2014). Bedford and Spriggs (2008) have earlier concluded that there is little archaeological support for a second wave of migration Post-Lapita from Melanesia into Vanuatu. This is now reconciled with the new Teouma data by suggesting that the Teouma people represented a very early settlement by biologically distinct people, who could be Polynesian ancestors, and that other Lapita populations of a more biologically Melanesian character soon followed, not as a separate event but as part of the Lapita expansion; although the authors still speak of additional migrations (Valentin et al. 2016). Whether the Early Lapita movement is found to be a distinctive event by an ancestral Polynesian subset of the cultural and biological geography of the Bismarck Archipelago is a new hypothesis that will take considerable work to resolve. What is clear is that the simple association of Lapita culture, biology and language needs to be reconsidered, and that it is very probable that the world of Island Melanesia was as complicated 3000 years ago as it is today. 


\section{Acknowledgements}

I would like to thank my many colleagues who have worked with me over the years and the new research teams working in the Solomon Islands who are slowly piecing together the prehistory of this fascinating area. In particular I would acknowledge the support of the National Museum, and its directors - Lawrence Foana'ota and then Tony Heorake — and my friends Kenneth Roga and John Keopo. Sadly John, who was the longest-serving archaeologist in the Solomon Island Museum, died in October 2014. A scholar of Ontong Java, he will be missed. Briar Sefton is thanked for producing the figures including the adaptation of Figure 7.3, which is reproduced with the permission of the publisher Oxford University Press.

\section{References}

Bedford, S. and M. Spriggs 2008. Northern Vanuatu as a Pacific crossroads: The archaeology of discovery, interaction, and the emergence of the 'ethnographic present'. Asian Perspectives 47(1):95-120. doi.org/ 10.1353/asi.2008.0003.

Black, S. and R. Green 1975. Radiocarbon dates from the British Solomon Islands to December 1973. Working Paper 39, Department of Anthropology University of Auckland.

Blackwood, B. 1935. Both sides of Buka Passage: An ethnographical study of social, sexual and economic questions in the north-eastern Solomon Islands. Clarendon Press, Oxford.

Blake, N., M. Gibbs and D. Roe 2015. Revised radiocarbon dates for Mwanihuki, Makira: A c. 3000 BP aceramic site in the Southeast Solomon Islands. Journal of Pacific Archaeology 6(2):56-64.

Blust, R. 2005. Review of Lynch, Ross and Crowley 2002. Oceanic Linguistics 44(2):544-558. doi.org/ 10.1353/ol.2005.0030.

Blust, R. 2008. Remote Melanesia: One history or two? An addendum to Donohue and Denham. Oceanic Linguistics 47(2):445-459. doi.org/10.1353/ol.0.0012.

Carter, M., D. Roe and J. Keopo 2012. Recent recoveries of archaeological ceramics on Santa Isabel, Central Solomon Islands. Journal of Pacific Archaeology 3:62-68.

Cath-Garling, S. 2017. Evolutions or revolutions? Interaction and transformation at the 'transition' in Island Melanesia. University of Otago Studies in Archaeology 27. University of Otago, Dunedin.

Chikamori, M. 1967. Preliminary report on archaeological research in the Western Solomons. In S. Itoh and M. Chickamori (eds), A brief report on research into the prehistory and anthropology of various islands in the British Solomon Islands Protectorate, pp. 1-26. The Authors, Hamamatsu.

Chowning, A. 1982. Physical anthropology, linguistics and biological anthropology. In J.L. Gressitt (ed.), Biogeography and ecology of New Guinea, pp. 131-168. W. Junk, The Hague. doi.org/10.1007/97894-009-8632-9_7.

Cox, M. 2007. Extreme patterns of variance in small populations: Placing limits on human Y-Chromosome diversity through time in the Vanuatu Archipelago. Annals of Human Genetics 71(3):390-406. doi.org/10.1111/j.1469-1809.2006.00327.x.

Cox, M. and M.M. Lahr 2006. Y Chromosome diversity is inversely associated with language affiliation in paired Austronesian and Papuan-speaking communities from Solomon Islands. American Journal of Human Biology 18:35-50. doi.org/10.1002/ajhb.20459.

Davenport, W. 1972. Preliminary excavations on Santa Ana Island, eastern Solomon Islands. Archaeology and physical anthropology in Oceania 7(3):165-183. 
David, B., I.J. McNiven, T. Richards, S.P. Connaughton, M. Leavesley, B. Barker and C. Rowe 2011. Lapita sites in the Central Province of mainland Papua New Guinea. World Archaeology 43(4):576593. doi.org/10.1080/00438243.2011.624720.

Delfin, F., S. Myles, Y. Choi, D. Hughes, R. Illek, M. van Oven, B. Pakendorf, M. Kayser and M. Stoneking 2012. Bridging Near and Remote Oceania: MtDNA and NRY variation in the Solomon Islands. Molecular Biology and Evolution 29(2):545-564. doi.org/10.1093/molbev/msr186.

Donohue, M. and T. Denham 2008. The language of Lapita: Vanuatu and an early Papuan presence in the Pacific. Oceanic Linguistics 47(2):433-444. doi.org/10.1353/ol.0.0021.

Donohue, M. and T. Denham 2010. Farming and language in Island Southeast Asia: Reframing Austronesian history. Current Anthropology 51(2):223-256. doi.org/10.1086/650991.

Duggan, A., B. Evans, F. Friedlaender, J. Friedlaender, G. Koki, D. Merriwether, M. Kayser and M. Stoneking 2014. Maternal history of Oceania from complete mtDNA genomes: Contrasting ancient diversity with recent homogenization due to the Austronesian expansion. The American Journal of Human Genetics 94(5):721-733. doi.org/10.1016/j.ajhg.2014.03.014.

Felgate, M. 2001. A Roviana ceramic sequence and the prehistory of Near Oceania: Work in progress. In G.R. Clark, A.J. Anderson and T. Sorovi-Vunidilo (eds), The archaeology of Lapita dispersal in Oceania. Papers from the fourth Lapita conference, June 2000, Canberra, Australia, pp. 39-60. Terra Australis 17. Pandanus Books, The Australian National University, Canberra.

Felgate, M. 2003. Reading Lapita in Near Oceania: Intertidal and shallow-water pottery scatters, Roviana Lagoon, New Georgia, Solomon Islands. Unpublished PhD thesis, University of Auckland, Auckland.

Friedlaender, J., F. Gentz, K. Green and D.A. Merriwether 2002. A cautionary tale on ancient migration detection: Mitochondrial DNA variation in Santa Cruz Islands, Solomon Islands. Human Biology 74(3):453-472. doi.org/10.1353/hub.2002.0029.

Friedlaender, J., F. Gentz, F. Friedlaender, F. Kaestle, T. Schurr, G. Koki, M. Schanfield, J. McDonough, L. Smith, S. Cerchio, C. Mgone and D.A. Merriwether 2005a. Mitochondrial genetic diversity and its determinants in Island Melanesia. In A. Pawley, R. Attenborough, J. Golson and R. Hide (eds), Papuan pasts: Cultural, linguistic and biological histories of Papuan-speaking peoples, pp. 693-716. Pacific Linguistics 572. RSPAS, The Australian National University, Canberra.

Friedlaender, J., T. Schurr, F. Gentz, G. Koki, F. Friedlaender, G. Babb, S. Cerchio, F. Kaestle, M. Schanfield, R. Deka, R. Yanagihara and D.A. Merriwether 2005b. Expanding Southwest Pacific mitochondrial haplogroups P and Q. Molecular Biology and Evolution 22(6):1506-1517. doi.org/ $10.1093 / \mathrm{molbev} / \mathrm{msi} 142$.

Friedlaender, J., F. Friedlaender, J. Hodgson, M. Stoltz, G. Koki, G. Horvat, S. Zhadanov, T. Schurr and A. Merriwether 2007. Melanesian mtDNA complexity. PLoS ONE 2(2):e248. doi.org/10.1371/ journal.pone.0000248.

Garanger, J. 1971. Incised and applied relief pottery, its chronology and development in southeastern Melanesia, and extra areal comparisons. In R.C. Green and M. Kelly (eds), Studies in Oceanic culture history, Volume 2, pp. 53-66. Pacific Anthropological Records 12. Department of Anthropology, Bernice P. Bishop Museum, Honolulu.

Garling, S. 2003. Tanga takes to the stage: Another model 'transitional' site? New evidence and a contribution to the 'Incised and Applied Relief Tradition' in New Ireland. In C. Sand (ed.), Pacific archaeology: Assessments and prospects. Proceedings of the conference for the 50th anniversary of the first Lapita excavation, Kone-Nouméa, 2002, pp. 213-233. Les cahiers de l'archéologie en NouvelleCalédonie 15. Département Archéologie, Service des Musées et du Patrimoine de NouvelleCalédonie, Nouméa. 
Gibbs, M. 2011. Beyond the New World-Exploring the failed Spanish colonies of the Solomon Islands. In M.P. Leone and J.M. Schablitsky (eds), Historical archaeology and the importance of material things II, pp. 143-166. Society for Historical Archaeology, Rockville.

Golson, J. 1971. Lapita ware and its transformations. In R.C. Green and M. Kelly (eds), Studies in Oceanic culture history, Volume 2, pp. 67-76. Department of Anthropology, Bernice P. Bishop Museum, Honolulu.

Golson, J. 1991. Two sites at Lasigi, New Ireland. In J. Allen and C. Gosden (eds), Report of the Lapita Homeland Project, pp. 244-259. Occasional Papers in Prehistory 20. Department of Prehistory, $\mathrm{RSPacS}$, The Australian National University, Canberra.

Gray, R.D., A.J. Drummond and S.J. Greenhill 2009. Language phylogenies reveal expansion pulses and pauses in Pacific settlement. Science 323(5913):479-483. doi.org/10.1126/science.1166858.

Green, R.C. 1976. Languages of the southeast Solomons and their historical relationships. In R.C. Green and M.M. Cresswell (eds), Southeast Solomon Islands culture history: A preliminary survey, pp. 47-60. Royal Society of New Zealand Bulletin 11. The Royal Society of New Zealand, Wellington.

Green, R.C. 1978. Notes on adze flakes, oven stones, pumice, muscovite-garnet-schist and metamorphosed sandstone specimens from the Main Reef/Santa Cruz Lapita sites, southeast Solomons. In W.R. Dickinson, P.R. Moore and R.C. Green (eds), Studies in sourcing of materials from the southeast Solomons, pp. 29-35. Oceanic Prehistory Records 7. Department of Anthropology, University of Auckland.

Green, R.C. 1979. Lapita. In J.D. Jennings (ed.), The prehistory of Polynesia, pp. 27-60. Harvard University Press, Cambridge, Mass. doi.org/10.4159/harvard.9780674181267.c3.

Green, R.C. 1988. Those mysterious mounds are for the birds. Archaeology in New Zealand 31:153-158.

Green, R.C. and M.M. Cresswell (eds) 1976. Southeast Solomon Islands cultural history: A preliminary survey. Royal Society of New Zealand Bulletin 11. Royal Society of New Zealand, Wellington.

Green, R.C. and J. Mitchell 1983. New Caledonia culture history: A review of the archaeological sequence. New Zealand Journal of Archaeology 5:19-67.

Haas, H., T. Braje, M. Lauer, S. Fitzpatrick, L. Kiko and G. Ale'eke 2018. Archaeological reconnaissance and the first radiocarbon dates from Simbo Island, Western Province, Solomon Islands. Journal of Pacific Archaeology 9(1):63-69.

Howells, W. 1973. Cranial variation in man. A study by multivariate analysis of patterns of difference among recent human populations. Papers of the Peabody Museum of Archaeology and Ethnology 67:1-259.

Irwin, G. 1972. An archaeological survey in the Shortland Islands, B.S.I.P. Unpublished MA thesis, University of Auckland, Auckland.

Irwin, G. 1989. Against, across and down the wind: A case for the systematic exploration of the Pacific Islands. Journal of the Polynesian Society 98(2):167-206.

Irwin, G. 2008. Pacific seascapes, canoe performance, and a review of Lapita voyaging with regard to theories of migration. Asian Perspectives 47(1):12-27. doi.org/10.1353/asi.2008.0002.

Kayser, M. 2010. The human genetic history of Oceania: Near and remote views of dispersal. Current Biology 20(4):R194-R201. doi.org/10.1016/j.cub.2009.12.004.

Kennett, D., A. Anderson and B. Winterhalder 2006. The ideal free distribution, food production, and the colonization of Oceania. In D.J. Kennett and B. Winterhalder (eds), Behavioral ecology and the transition to agriculture, pp. 265-288. University of California Press, Berkeley. 
Kouneski, E. 2009. Mitochondrial DNA origins and affinities of the Kanak of New Caledonia. Unpublished MA thesis, State University of New York at Binghamton.

Lincoln, P. 1976. History of research in Austronesian languages: Bougainville Province. In A.S. Wurm (ed.), New Guinea Area languages and language study, Vol. 2: Austronesian languages, pp. 197-222. Pacific Linguistics C-39. RSPacS, The Australian National University, Canberra.

Lipson, M., P. Skoglund, M. Spriggs, F. Valentin, S. Bedford, R. Shing, H. Buckley, I. Phillip, G. Ward, S. Mallick, N. Rohland, N. Broomandkhoshbacht, O. Cheronet, M. Ferry, T. Harper, M. Michel, J. Oppenheimer, K. Sirak, K. Stewardson, K. Auckland, A. Hill, K. Maitland, S. Oppenheimer, T. Parks, K. Robson, T. Williams, D. Kennett, A. Mentzer, R. Pinhasi and D. Reich 2018. Population turnover in Remote Oceania shortly after initial settlement. Current Biology 28(7):1157-1165 and Supplementary Information. doi.org/10.1016/j.cub.2018.02.051.

Lynch, J, M. Ross and T. Crowley 2002. The Oceanic languages. Curzon Press, Surrey.

Merriwether, D.A., J.S. Friedlaender, J. Mediavilla, C. Mgone, F. Gentz and R.E. Ferrell 1999. Mitochondrial DNA is an indicator of Austronesian influence in Island Melanesia. American Journal of Physical Anthropology 110:243-270. doi.org/10.1002/(SICI)1096-8644(199911)110:3<243::AIDAJPA1>3.0.CO;2-M.

Merriwether, D.A., J.A. Hodgson, F.R. Friedlaender, R. Allaby, S. Cerchio, G. Koki and J.S. Friedlaender 2005. Ancient mitochondrial M Haplogroups identified in the Southwest Pacific. Proceedings of the National Academy of Sciences of the United States of America 102(37): 13034-13039.

Miller, D. 1979. National sites survey summary report. Solomon Islands National Museum, Honiara.

Miller, D. 1980. Settlement and diversity in the Solomon Islands. Man 15:451-466. doi. org/10.2307/2801344.

Naess, A.. and B. Boerger. 2008. Reefs-Santa Cruz as Oceanic: Evidence from the verb complex. Oceanic Linguistics 47(1):185-212. doi.org/10.1353/ol.0.0000.

Pawley, A. 2006. Explaining the aberrant Austronesian languages of southeast Melanesia: 150 years of debate. Journal of the Polynesian Society 115(3):215-258.

Pawley, A. 2009. The role of the Solomon Islands in the first settlement of Remote Oceania: Bringing linguistic evidence to an archaeological debate. In A. Adelaar and A. Pawley (eds), Austronesian historical linguistics and culture history: A festschrift for Robert Blust, pp. 515-540. Pacific Linguistics 601. RSPAS, The Australian National University, Canberra.

Pietrusewsky, M., H. Buckley, D. Anson and M. Douglas 2014. Polynesian origins: A biodistance study of mandibles from the Late Lapita site of Reber-Rakival (SAC), Watom Island, Bismarck Archipelago. Journal of Pacific Archaeology 5(1):1-20.

Posth, C., K. Nägele, H. Colleran, F. Valentin, S. Bedford, K. Kami, R. Shing, H. Buckley, R. Kinaston, M. Walworth, G. Clark, C. Reepmeyer, J. Flexner, T. Maric, J. Moser, J. Gresky, L. Kiko, K. Robson, K. Auckland, S. Oppenheimer, A. Hill, A. Mentzer, J. Zech, F. Petchey, P. Roberts, C. Jeong, R. Gray, J. Krause and A. Powell 2018. Language continuity despite population replacement in Remote Oceania. Nature Ecology and Evolution 2:731-740. doi.org/10.1038/s41559-018-0498-2.

Pugach, I., A. Duggan, D.A. Merriwether, F. Friedlaender, J. Friedlaender and M. Stoneking 2018. The gateway from Near into Remote Oceania: New insights from genome-wide data. Molecular Biology and Evolution 35(4):871-886. doi.org/10.1093/molbev/msx333.

Reeve, R. 1989. Recent work on the prehistory of the Western Solomons, Melanesia. Bulletin of the Indo-Pacific Prehistory Association 9:46-67. doi.org/10.7152/bippa.v9i0.11282.

Richards, R. 2011. A probable Lapita site in the western Solomon Islands? Archaeology in Oceania 46(3):139-140. doi.org/10.1002/j.1834-4453.2011.tb00108.x. 
Roe, D. 1993. Prehistory without pots: Prehistoric settlement and economy of north-west Guadalcanal, Solomon Islands. Unpublished PhD thesis, The Australian National University, Canberra.

Ross, M. 1988. Proto-Oceanic and the Austronesian languages of Western Melanesia. Pacific Linguistics C-98. RSPacS, The Australian National University, Canberra.

Ross, M and Å. Naess 2007. An Oceanic origin for Äiwoo, the language of the Reef Islands? Oceanic Linguistics 46(1):456-498. doi.org/10.1353/ol.2008.0003.

Rukia, A. 1989. Early usages of rockshelters and caves in Solomon Islands: Ngella Pile, Central Islands Province. 'O`O, A Journal of Solomon Islands Studies 2(1):26-47.

Russell, T. 2003. I have the honour to be. The Memoir Club, Spennymoor.

Sheppard, P.J. 1993. Lapita lithics: Trade/exchange and technology. A view from the Reefs/Santa Cruz. Archaeology in Oceania 28(3):121-137. doi.org/10.1002/j.1834-4453.1993.tb00303.x.

Sheppard, P.J. 1996. Hard rock: Archaeological implications of chert sourcing in Near and Remote Oceania. In J. Davidson, G. Irwin, B. Leach, A. Pawley and D. Brown (eds), Oceanic culture history: Essays in honour of Roger Green, pp. 99-115. New Zealand Journal of Archaeology Special Publication, Dunedin.

Sheppard, P.J. 2011. Lapita colonization across the Near/Remote Oceania Boundary. Current Anthropology 52(6):799-840. doi.org/10.1086/662201.

Sheppard, P. and R. Walter 2006. A revised model of Solomon Islands culture history. Journal of the Polynesian Society 115:47-76.

Sheppard, P., M, Felgate, K. Roga, J. Keopo and R. Walter 1999. A ceramic sequence from Roviana Lagoon (New Georgia, Solomon Islands). In J.-C. Galipaud and I. Lilley (eds), The Pacific from 5000-2000 BP: Colonisation and transformations, pp. 313-322. IRD Éditions, Paris.

Sheppard, P., R. Walter and K. Roga 2010. Friends, relatives, and enemies: The archaeology and history of interaction among Austronesian and NAN speakers in the Western Solomons. In J. Bowden, N. Himmelmann and M. Ross (eds), A journey through Austronesian and Papuan linguistic and cultural space: Papers in honour of Andrew K. Pawley, pp. 95-112. Pacific Linguistics 615. RSPAS, The Australian National University, Canberra.

Sheppard, P., R. Walter, W.R. Dickinson, M. Felgate, C. Ross-Sheppard and C. Azémard 2015a. A Solomon Sea interaction sphere? In C. Sand, S. Chiu and N. Hogg (eds), The Lapita Cultural Complex in time and space: Expansion routes, chronologies and typologies, pp. 63-80. Archeologia Pasifika 4. Institut d'archéologie de la Nouvelle-Calédonie et du Pacifique (IANCP), Nouméa.

Sheppard, P., S. Chiu and R. Walter 2015b. Re-dating Lapita movement into Remote Oceania. Journal of Pacific Archaeology 6(1):26-36.

Shutler, R. and M. Shutler. 1964. Potsherds from Bougainville Island. Asian Perspectives 8:181-183.

Skoglund, P., C. Posth, K. Sirak, M. Spriggs, F. Valentin, S. Bedford, G. Clark, C. Reepmeyer, F. Petchey, D. Fernandes, Q. Fu, E. Harney, M. Lipson, S. Mallick, M. Novak, N. Rohland, K. Stewardson, S. Abdullah, M. Cox, F. Friedlaender, J. Friedlaender, T. Kivisild, G. Koki, P. Kusuma, A. Merriwether, F.-X. Ricaut, J. Wee, N. Patterson, J. Krause, R. Pinhasi and D. Reich 2016. Genomic insights into the peopling of the Southwest Pacific. Nature 538(7626):510-513 and Supplementary Information. doi.org/10.1038/nature19844.

Soares, P., T. Rito, J. Trejaut, M. Mormina, C. Hill, E. Tinkler-Hundal, M. Braid, D. Clarke, J. Loo and N. Thomson. 2011. Ancient voyaging and Polynesian origins. The American Journal of Human Genetics 88 (2):239-247. doi.org/10.1016/j.ajhg.2011.01.009. 
Specht, J. 1969. Prehistoric and modern pottery industries of Buka Island, T.P.N.G., Unpublished PhD thesis, The Australian National University, Canberra.

Spriggs, M. 1991. Nissan: The island in the middle. Summary report on excavations at the north end of the Solomons and south end of the Bismarcks. In J. Allen and C. Gosden (eds), Report of the Lapita Homeland Project, pp. 222-243. Occasional Papers in Prehistory 20. Department of Prehistory, RSPacS, The Australian National University, Canberra.

Spriggs, M. 1997. The Island Melanesians. Blackwell, Oxford.

Spriggs, M. 2011. Archaeology and the Austronesian expansion: Where are we now? Antiquity 85(328):510-528. doi.org/10.1017/S0003598X00067910.

Swadling, P. 1976. The Occupation sequence and settlement pattern on Santa Ana. In R.C. Green and M.M. Cresswell (eds), Southeast Solomon Islands cultural history: A preliminary survey, pp. 123-132. Royal Society of New Zealand Bulletin 11. The Royal Society of New Zealand, Wellington.

Terrell, J. 1976. Perspectives on the prehistory of Bougainville Island, Papua New Guinea: A study in the human biogeography of the southwestern Pacific. Unpublished PhD thesis. Department of Anthropology, Harvard University, Cambridge, Mass.

Thomas, T. 2009. Communities of practice in the archaeological record of New Georgia, Rendova and Tetepare. In P. Sheppard, T. Thomas and G. Summerhayes (eds), Lapita: Ancestors and descendants, pp. 119-145. New Zealand Archaeological Association Monograph 28. New Zealand Archaeological Association, Auckland.

Tochilin, C., W.R. Dickinson, M. Felgate, M. Pecha, P. Sheppard, F. Damon, S. Bickler and G. Gehrels 2012. Sourcing temper sands in ancient ceramics with U-Pb ages of detrital zircons: A Southwest Pacific test case. Journal of Archaeological Science 39(7):2583-2591. doi.org/10.1016/j.jas.2012.04.002.

Valentin, F., F. Détroit, M. Spriggs and S. Bedford 2016. Early Lapita skeletons from Vanuatu show Polynesian craniofacial shape: Implications for Remote Oceanic settlement and Lapita origins. Proceedings of the National Academy of Sciences 113(2):292-297 and Supplementary Information. doi.org/10.1073/pnas.1516186113.

Van Oven, M., Silke B., Y. Choi, J. Ensing, W. Schiefenhovel, M. Stoneking and M. Kayser 2014. Human genetics of the Kula Ring: Y-chromosome and mitochondrial DNA variation in the Massim of Papua New Guinea. European Journal of Human Genetics 22(12):1393-1403. doi.org/10.1038/ ejhg.2014.38.

Walter, R. and P. Sheppard. 2009. A review of Solomon Island archaeology. In P. Sheppard, T. Thomas and G. Summerhayes (eds), Lapita: Ancestors and descendants, pp. 35-72. New Zealand Archaeological Association Monograph Series 28. New Zealand Archaeological Association, Auckland.

Walter, R., C. Jacomb and S. Bowron-Muth 2010. Colonisation, mobility and exchange in New Zealand prehistory. Antiquity 84(324):497-513. doi.org/10.1017/S0003598X00066734.

Ward, G. 1976. The archaeology of settlements associated with the chert industry at Ulawa. In R.C. Green and M.M. Cresswell (eds), Southeast Solomon Islands cultural history: A preliminary survey, pp. 161-180. Royal Society of New Zealand Bulletin 11. The Royal Society of New Zealand, Wellington.

Welsch, R., J. Terrell and J. Nadolski 1992. Language and culture on the north coast of New Guinea. American Anthropologist 94:568-600. doi.org/10.1525/aa.1992.94.3.02a00030.

White, P. and C. Murray-Wallace 1996. Site ENX (Fissoa) and the incised and applied pottery tradition in New Ireland, Papua New Guinea. Man and Culture in Oceania 12:31-46.

Wickler, S. 2001. The prehistory of Buka: A stepping stone island in the northern Solomons. Terra Australis 16. Department of Archaeology and Natural History and Centre for Archaeological Research. The Australian National University, Canberra. 
This text is taken from Debating Lapita: Distribution, Chronology, Society and Subsistence, edited by Stuart Bedford and Matthew Spriggs, published 2019 by ANU Press,

The Australian National University, Canberra, Australia.

doi.org/10.22459/TA52.2019.07 